\title{
Current Understanding of Fungal Microflora in Inflammatory Bowel Disease Pathogenesis
}

\author{
David Underhill, $\mathrm{PhD}^{*}, \dagger$ and Jonathan Braun, MD, PhD* \\ *The Department of Pathology and Laboratory Medicine, David Geffen School of Medicine at \\ UCLA, Los Angeles, California \\ †The Immunobiology Research Institute, Cedars-Sinai Medical Center, Los Angeles, California
}

\begin{abstract}
Inflammatory bowel diseases are a current and growing public health problem, with a prevalence that appears to be increasing in most countries and cultures. While most research into the triggering phenomenon has focused on the interaction between commensal bacteria and inflammatory bowel disease, enteric fungi may also be important in determining disease susceptibility. Herein we review what is known about enteric fungi and the mechanisms by which they and their dysregulation might be involved in triggering inflammatory diseases of the bowel.
\end{abstract}

\section{Keywords}

enteric fungi; microbiota; pathogenesis; IBD; innate immunity; disease biomarker; dectin; toll

\section{ASSOCIATIONS OF GUT MICROBIOTA AND INFLAMMATORY BOWEL DISEASES}

It has long been recognized that microbiota of the gut are a trigger for a range of inflammatory bowel diseases (IBDs), particularly Crohn's disease (CD). The dramatic increase in IBD in North America and Europe-some 20-fold in the years since World War II-is likely due in large part to changes in enteric microbiota due to diet or other environmental events. A similar trend in IBD has been more recently seen in rapidly Westernizing East Asia, pointing to a growing global effect.

In response to this public health shift, significant effort has been expended to discern which organisms are at play and how best to combat them. General dysbiosis has been of particular interest. Pace and colleagues ${ }^{1}$ recently reported that a subset of $\mathrm{CD}$ and ulcerative colitis (UC) patients had a notable depletion of members of the phyla Firmicutes and Bacteroidetes and other investigations have shown that successful prolongation of remission using probiotics is associated with the development of increased bacterial diversity in the gut. ${ }^{2}$ Throughout these investigations the focus has primarily been on enteric bacteria, specifically, such organisms as enteroadhesive $E \cdot \operatorname{col}^{3-6}$; bacteria bearing distinct flagellin subclass ${ }^{7}$; and M. avium paratuberculosis. ${ }^{8-13}$

However, early evidence suggests that the fungal microbiota could also be of substantial and underappreciated importance in the genesis and maintenance of IBDs. Using molecular

(C) 2008 Crohn's \& Colitis Foundation of America, Inc.

Reprints: Jonathan Braun, Department of Pathology and Laboratory Medicine, David Geffen School of Medicine at UCLA, Los Angeles, CA 90095 (jbraun@mednet.ucla.edu). 
methods, we established that the fungal component of the intestinal microbiota in mice is large and diverse. ${ }^{14}$ Subsequently, Schreiber and colleagues ${ }^{15}$ found that the diversity of the fungal flora was suppressed in patients receiving a probiotic for-and successfully establishing - remission of pouchitis (a postsurgical complication in patients with UC). At the same time, the number and variety of bacterial species in the mucosal flora was increased, suggesting a balance between the diversity of fungal and bacterial species. These interesting findings suggest that enteric fungi deserve a fresh look as a microbial factor in the biology of disease susceptibility in $\mathrm{CD}$. In this review we explore what is known about fungi and intestinal diseases as well as the current state of the literature regarding mechanisms of fungal recognition in the gut.

\section{PATIENTS AND ASCA}

Anti-Saccharomyces cerevisiae antibodies (ASCA) are directed against a common fungal cell wall epitope. ${ }^{16}$ ASCA was the first biomarker that was capable of identifying the majority of patients with $\mathrm{CD}$ and it remains the single most robust biomarker manifestation of $\mathrm{CD},{ }^{17-20}$ although recent work has demonstrated additional diagnostic value in multiple analytes, including novel markers (antilaminaribioside and antichitobioside carbohydrate antibodies). ${ }^{21}$ The exact stimulus for the development of ASCA is unknown ${ }^{22}$ and complicated by the fact that there is significant crossreactivity with multiple different yeast species, including $S$. cerevisiae but also Candida albicans. ${ }^{23,24}$ Interestingly, experiments in human tissue have demonstrated the ability of $C$. albicans growth to induce ASCA production. ${ }^{25}$ Alternatively, it has also been suggested that the response could be due to the ingestion of dietary antigens, ${ }^{26,27}$ and lymphocytes of ASCA-positive patients (but not healthy controls ${ }^{28}$ or UC patients ${ }^{29}$ ) have been shown to proliferate after activation with yeast or yeast antigens.

While ASCA positivity is a robust marker for $\mathrm{CD}$, a substantial subgroup of Crohn's patients is negative for ASCA. Vermeire et $\mathrm{al}^{33 \%}$ found that CD patients in mixed Crohn's families actually had a very low rate of ASCA positivity, but that nearly a quarter of unaffected family members were ASCA-positive in CD families. ${ }^{30}$ Similar results were found in other studies of patients with CD or UC and their first-degree relatives, where up to one-quarter of disease-free relatives of CD patients were also positive for ASCA, ${ }^{31,32}$ although there was no significant association between ASCA and UC. We found that more than $50 \%$ of $\mathrm{CD}$ patients and $\mathrm{CD}$-affected family members were seropositive for antimannan Ig, with significant aggregation even among unaffected family members. ${ }^{33} \mathrm{In}$ contrast, married couples showed no significant concordance, indicating that the concordance among family members was either genetic or due to early childhood environmental factors. ${ }^{33}$ It should be noted that there is evidence to suggest that the presence of ASCA could predict the development of disease before diagnosis, ${ }^{34}$ so at least some of the disease-free, ASCA-positive controls in these various studies might not yet have manifested the disease.

The presence of ASCA does not simply indicate presence (or likelihood of development) of $\mathrm{CD}$. It has been shown that ASCA-positive patients are more likely to have gastroduodenal and small bowel involvement rather than colonic disease; they were also shown to be more likely to have more severe disease and to require surgery within a 9-year follow-up period. ${ }^{35}$ Similarly, pediatric patients who required surgery demonstrated an association between ASCA positivity and an increased risk for surgery. ${ }^{36}$ In addition to ASCA, several other serological markers have been identified that appear to be associated with distinct disease courses, ${ }^{37}$ including the need for surgery or the severity or complications of the disease. ${ }^{38}$ Our group assessed the serum responses of CD patients in a separate study of some of the same microbial antigens and autoantigens. We found that patients fell into 1 of several 
subgroups with respect to antibody responses, and, moreover, that the individual patients' responses were stable over time, pointing to a variety of patient subsets based on intrinsic traits. $^{3}$

\section{GENETIC ASSOCIATIONS WITH CD}

Significant work has gone into identifying the gene or genes associated with CD susceptibility, as well as susceptibility to other inflammatory bowel diseases. Such studies have further underscored the distinction between, for example, CD and UC: comparative studies of CD and UC demonstrated significant differences in gene expression ${ }^{39}$ and cDNA profiles. ${ }^{40}$

Through linkage analysis, associations with IBD were seen with markers on chromosome 16. ${ }^{41,42}$ Other linkage studies suggested possible loci on chromosomes 1,3 , and $4,{ }^{43} 5,{ }^{44}$ and $12 .{ }^{45} \mathrm{~A}$ number of genes have been proposed as having an association with $\mathrm{CD}$ susceptibility, including those encoding for IL23R, ${ }^{46}$ the vitamin $\mathrm{D}$ receptor, ${ }^{47}$ the interleukin 10 receptor alpha chain, ${ }^{48}$ interleukin $18,{ }^{48}$ and peroxisome proliferatoractivated receptor gamma. ${ }^{49}$ Other candidates have been explored but ruled out, including NRAMP $2 .{ }^{50}$ In a recent genome-wide association study, Rioux et $\mathrm{al}^{51}$ identified associations between $\mathrm{CD}$ and variations in the intergenic region on 10q21.1, and the genomic regions encoding ATG16L1, PHOX2B, NCF4, and a predicted gene on 16q24.1 (FAM92B).

Overall, however, the most well-established association is with an insertion mutation in the NOD2/CARD15 gene on chromosome 16; family-based association analyses were consistently positive with $\mathrm{CD}$ patients but not positive with either healthy controls or UC patients and the genotype-specific disease risks were substantial (2.6 for heterozygotes and 42.1 for homozygotes). ${ }^{52}$ The importance of NOD2 was further confirmed when, in a NOD2-deficient mouse model, it was shown that colitis could be induced with only a single antigen (E. coli-expressing OVA peptide) ${ }^{53} \mathrm{~A}$ mutant form of NOD2 is present in up to $20 \%$ of Caucasian CD patients. It has been demonstrated that certain NOD2 alleles are associated with delayed progression of disease (which itself is associated with less frequent need for surgery; similarly, presence of ASCA was associated with rapid progression ${ }^{54}$ ) and this was true in both familial and sporadic cases. ${ }^{55}$ In patients with wildtype NOD2, the subset of patients who were high TNF- $a$ producers were protected against development of IgA-ASCA, but this association was not seen in patients with NOD2 mutations. ${ }^{56}$ Moreover, patients who were ASCA-positive have been shown to have a greater frequency of NOD2 mutations, although the associations between ASCA levels and severity or progression of disease were found to be independent of NOD2 mutation status. ${ }^{57}$

\section{INNATE MECHANISMS FOR RECOGNITION OF FUNGI AND ACTIVATION OF INFLAMMATORY RESPONSES}

Very little is known about how the innate immune system in the gut recognizes and responds to fungi. Recent studies on how bacteria induce intestinal inflammation have successfully demonstrated roles for innate immune receptors such as Toll-like receptors (TLRs) that were first described in nonmucosal contexts. Similarly, it is also possible that fungal recognition in the gut is regulated by receptors that have been previously described in other contexts.

As listed in Table 1, a variety of proteins have been identified that participate in innate fungal recognition and regulation of inflammatory responses. Soluble proteins such as the mannose binding protein (MBP) and pentraxin 3 function primarily to promote complement deposition on target cells and killing. As these proteins circulate in serum, it is unlikely that 
they would play important roles in detecting gut fungi unless breakdown in the epithelial barrier allows systemic appearance of fungi. More promising, a variety of membrane receptors that bind to fungi and influence inflammatory responses have been identified, and these receptors are expressed by macrophages and dendritic cells found in mucosal tissues. Below is a discussion of these receptors and their contributions to antifungal immunity.

\section{TOLL-LIKE RECEPTORS}

Toll-like receptors are a family of innate immune receptors that recognize many types of microbes. For example, TLR4 recognizes lipopolysaccharide from the cell wall of Gramnegative bacteria, while TLR3 recognizes double-stranded RNA viruses. That TLRs are involved in recognition of fungi has been clear from the earliest studies on the topic. The demonstration that Toll-deficient Drosophila are highly susceptible to Aspergillus infection, ${ }^{58}$ combined with the observation that mammals possess homologs of Drosophila Toll, was strongly indicative of a role for TLRs in mammalian antifungal responses. Subsequent studies have demonstrated that both TLR2 and TLR4 variously contribute to recognition of fungal pathogens.

TLR2 is recruited to macrophage phagosomes containing zymosan, a cell wall preparation of $S$. cerevisiae, and the inflammatory response of macrophages to zymosan exposure is abrogated by expression of dominant-negative TLR2 or dominant-negative MyD88. ${ }^{59}$ TLR2 has since been demonstrated to be a key receptor for pathogenic fungi, including $C$. albicans, Aspergillus fumigatus, A. niger, Cryptococcus neoformans, Pneumocystis carinii, and Coccidioides posadasii. TLR2 must heterodimerize with TLR1 or TLR6 to be functional, although the precise requirement for TLRs 1 and 6 in fungal recognition has not been thoroughly explored. TLR1 and TLR6 colocalize with TLR2 on zymosan-containing phagosomes, and experimental expression of a inhibitory form of TLR6 blocks the inflammatory response of macrophages to the yeast cell wall particle zymosan. ${ }^{60}$

In addition, several studies have demonstrated roles for TLR4 (and CD14) in responses to $C$. albicans, A. fumigatus, A. niger, $C$. neoformans, and $P$. carinii. For example, Netea et al ${ }^{61}$ showed that TLR4 Pro712His mutant $(\mathrm{C} 3 \mathrm{H} / \mathrm{HeJ})$ mice display increased susceptibility to disseminated candidiasis due to impaired chemokine (KC and MIP-2) production and reduced neutrophil recruitment, although production of proinflammatory cytokines, including TNF- $a$, was only marginally influenced and the ability of phagocytes to kill Candida was not affected. In humans, TLR4 Asp299Gly/Thr399Ile polymorphisms are associated with increased susceptibility to systemic Candida infections, and peripheral blood mononuclear cells from individuals bearing these polymorphisms produce more IL-10 following in vitro exposure to $C$ albicans. ${ }^{62}$ Data also demonstrate that Aspergillus conidia and swollen conidia are detected by TLR4 in addition to TLR2. ${ }^{63-65}$

TLRs activate intracellular signaling through a family of related signaling adaptor molecules that includes MyD88, MAL, TRAM, and Trif. Ultimately, these signals drive activation of NF- $\kappa$ B and production of inflammatory cytokines and chemokines. TLRs and TLR signaling molecules have been implicated in regulating gut responses to microbes. In humans, polymorphisms in TLR4 (Asp299Gly) and Mal have been associated with human CD and UC. ${ }^{66,67}$ In mice, deficiency of MyD88, TLR4, or TLR2 has been shown to increase susceptibility in dextran sodium sulfate (DSS) models of colitis. ${ }^{68-70}$ Also, IL10 ${ }^{-/-}$mice develop spontaneous colitis that is dependent on MyD88. ${ }^{71}$ Although gut fungi may activate TLR2 and TLR4, these receptors are likely fully activated by bacteria, thus the contribution of fungal recognition is not clear. 


\section{B-GLUCAN RECOGNITION: DECTIN-1, CR3}

$\beta$-Glucan is the primary structural component of fungal cell walls. In Candida at least $40 \%$ of the dry weight of the cell wall is made up of this carbohydrate. ${ }^{72}$ Mammals seem to have evolved at least 2 ways to recognize fungal $\beta$-glucan. First, a C-type lectin receptor called Dectin- 1 binds $\beta$-glucan and triggers phagocytosis and inflammatory responses in myeloid phagocytes. Dectin-1 was originally cloned as a dendritic cell surface molecule capable of delivering costimulatory signals to T cells. ${ }^{73}$ It was subsequently shown to be expressed more widely on myeloid cells including macrophages, dendritic cells, and neutrophils. ${ }^{74}$ Dectin-1 is a member of the NK-like C-type lectin family and comprises an extracellular carbohydrate recognition domain, a 47 amino acid "stalk," a transmembrane region, and a 40 amino acid N-terminal cytoplasmic tail. The intracellular tail of Dectin-1 contains a sequence resembling an immunoreceptor tyrosine-based activation motif (ITAM), a signaling motif well known for its role in signaling by lymphocyte antigen receptors (TCR and $\mathrm{BCR}$ ) and $\mathrm{Fc}$ receptors. ITAM signaling following antigen receptor ligation is characterized by phosphorylation of the dual ITAM tyrosines by Src family kinases (reviewed previously ${ }^{75}$ ). This allows recruitment of Syk family kinases, which interact with the dual phosphotyrosines via their dual SH2 domains. Consistent with ITAM-like signaling, the intracellular tail of Dectin-1 is tyrosine phosphorylated upon ligand binding and requires Src and Syk family kinases, although only a single tyrosine appears to be required. ${ }^{76-79}$

Several recent studies now suggest that a protein called CARD9 is needed for Dectin-1 signaling downstream of Syk. CARD9 is a signaling adaptor molecule consisting of an Nterminal caspase activation and recruitment domain (CARD) and a C-terminal coiled-coil domain. CARD9 interacts with Bcl10 and Malt1 to activate NF- $\kappa$ B in a mechanism highly analogous to the CARMA1/Bcl10/Malt1 complex utilized in TCR signaling. As a result, bone marrow-derived dendritic cells from CARD9-deficient mice exhibited defective cytokine responses (TNF- $a$, IL-6, IL-2) to zymosan and yeast. ${ }^{80,81}$ Importantly, CARD9 has also been implicated in signaling by Nod2, another CARD-containing protein that is closely associated with innate immunity in the gut. Nod2 detects intracellular bacteria, and polymorphisms in Nod2 are strongly linked with CD. ${ }^{82}$ That recognition of bacteria (via Nod2) and fungi (via Dectin-1) leads to molecular signals through a shared signaling pathway creates a possible link between the observation that $\mathrm{CD}$ is associated with mutations in Nod2 and the presence of serum antibodies against yeast cell wall antigens (ASCA) described above.

A second receptor that may participate in recognition of yeast $\beta$-glucan is the complement receptor 3 (CR3, $a \mathrm{M} / \beta 2$ integrin). The $a \mathrm{M}$ chain of complement receptor 3 has a high affinity $\left(5 \times 10^{-8} \mathrm{M}\right) \beta$-glucan binding site. ${ }^{83}$ Indeed, antibodies to $a \mathrm{M} / \beta 2$ block binding and internalization of unopsonized zymosan, ${ }^{84}$ and patients with a deficiency in $\beta 2$ integrins show defects in phagocytosis of unopsonized zymosan. ${ }^{84}$ In these cases it is possible that $a \mathrm{M} / \beta 2$ inhibition indirectly modulates the affinity, expression, or function of Dectin-1. However, other studies have shown that soluble $\beta$-glucans (that activate Dectin-1 poorly or not at all) efficiently prime neutrophils for respiratory burst activity and killing of antibodyopsonized that is entirely dependent on CR3 expression. ${ }^{85}$

Integrins including CR3 have been demonstrated to activate phagocytes through mechanisms involving phosphoinositide 3-kinase, Rho family GTPases, and protein kinase $\mathrm{C}$ (PKC) family members. Interestingly, recent data clearly demonstrate that CR3 also signals through an Src/Syk-based mechanism analogous to that activated by Dectin-1. ${ }^{86}$ ROS production in response to a variety of $\beta 2$ integrin ligands is abrogated in Syk-deficient neutrophils. ${ }^{87}$ Although the specific role of CR3-mediated signaling through Syk in direct 
recognition of fungi has not been explored, $\mathrm{Li}$ et al ${ }^{85}$ have suggested that binding of small $\beta$ glucan fragments to CR3 is sufficient to activate Syk in neutrophils.

\section{MANNAN RECOGNITION: MANNOSE RECEPTOR, DC-SIGN, DC-SIGNR}

Like $\beta$-glucan, mannan is an abundant carbohydrate component of fungal cell walls. In the cell wall of $C$. albicans, for example, mannan is linked to surface proteins, and these mannoproteins make up $30 \%-40 \%$ of the cell wall dry weight. ${ }^{72}$ At least 2 membrane receptors for mannan participate in innate immune recognition of fungi. The macrophage mannose receptor is a type I transmembrane protein with a short 45 amino acid cytoplasmic tail. The extracellular domain of the receptor consists of $8 \mathrm{C}$-type lectin carbohydrate recognition domains (CRDs) together with a short amino terminal cysteine-rich region and a fibronectin type II repeat. ${ }^{88}$ The mannose receptor is expressed widely by phagocytes, including macrophages and dendritic cells. The mannose receptor has been demonstrated to participate in macrophage recognition of a variety of fungi including Saccharomyces, Candida, and Pneumocystis. ${ }^{88}$ Blockade of mannose receptor with specific antibodies or soluble mannan typically reduces phagocytosis and inflammatory cytokine production by macrophages challenged with fungi. However, very little is understood about the molecular mechanisms by which the mannose receptor signals. Some previous studies on mannose receptor recognition of fungi might be complicated by the recent observation that Dectin-2 also recognizes mannan and is expressed by macrophages ${ }^{89}$ Like Dectin-1, Dectin-2 is a type II C-type lectin receptor. Unlike Dectin-1, Dectin-2 appears to associate with the common Fc-R $\gamma$-chain $(\mathrm{FcR} \gamma)$ to drive intracellular signals. FcR $\gamma$ is an ITAM-containing surface protein that associates with $\mathrm{Fc} \gamma \mathrm{RI}$ and $\mathrm{Fc} \gamma \mathrm{RIII}$ to mediate signaling in response to antibody-opsonized targets..$^{90}$ The contribution of FcR $\gamma$ signaling to antifungal immune responses has not yet been explored directly.

Additional receptors expressed primarily on dendritic cells recognize fungal mannan and likely participate in shaping immune responses. DC-SIGN and DC-SIGNR recognize carbohydrates on the surfaces of many microbes, including viruses, bacteria, and fungi. They recognize terminal mannose residues in complex carbohydrates and bind to fungal cell walls in a manner that can be competed with soluble mannan. ${ }^{91-93}$ SIGNR1 (the mouse homolog of human DC-SIGNR) has been reported to bind to yeast and assist in internalization, although it appears to have a relatively minor influence on inflammatory responses; SIGNR1 overexpression in a macrophage cell line slightly enhances TNF- $a$ production induced by yeast cell walls while having a much greater effect on binding and internalization..${ }^{94}$ Mice deficient in SIGNR1 have a strongly Th1-polarized immune response to infection with Mycobacterium tuberculosis, suggesting that SIGNR1 might enhance inflammatory signaling, although this has not yet been further explored in the context of fungal recognition. ${ }^{95}$ DC-SIGN, on the other hand, seems to signal for suppression of inflammatory responses. Multiple studies have linked DC-SIGN recognition to enhanced IL-10 production and reduced cellular maturation by dendritic cells. Although the proximal signaling mechanisms have not been fully established, a recent report indicates that DC-SIGN signals through Raf-1 to cause acylation and inhibition of the transcription factor NF- $\kappa \mathrm{B}$. As a consequence, when dendritic cells are exposed to Candida they produce large amounts of IL-10 that is significantly inhibited if Raf-1 signaling is blocked. ${ }^{96}$ Thus, the role of mannan recognition in immune responses to fungi is likely defined by the repertoire of mannan-binding receptors on specific cell types. While mannan recognition by DC-SIGN on certain dendritic cells might drive a more antiinflammatory response, other DC-SIGN homologs or Dectin-2 expressed on other types of dendritic cells or macrophages might promote a more proinflammatory response. 


\section{CONCLUSION}

$\mathrm{CD}$ is associated with marked heterogeneity in its clinical presentation, but the underlying host trait is 1 or more, presumably genetic, factors that lead to an overreaction of the mucosal immune system to normally present flora. Although most available evidence has indicated a role for bacterial entities, there is tantalizing evidence that suggests that a balance between the diversity of the bacterial and fungal microflora could impact the development of CD.

While the underlying dysregulation of the mucosal immune system is presumably to that in other intestinal bowel diseases including UC, there are clearly substantial differences between the 2 that have profound implications for diagnosis, prognosis, and treatment. Not least of these differences is the presence of ASCA in CD, but not UC. This unique association indicates that the biology underlying the ASCA response will also align with biologic susceptibility traits for CD versus UC. ASCA is therefore likely to be an indirect but meaningful readout of the disease-susceptibility trait that is leading to the disease phenotype.

In summary, much is known and much more is beginning to be understood about the spectrum of disease presentations, including genetic bases and potential triggering events. Greater understanding of the disease heterogeneity will allow for improved management, treatment, and development of therapeutic interventions for patients across the spectrum of IBD.

\section{Acknowledgments}

Supported by National Institutes of Health (NIH) grants DK46763 (to J.B.), DK69434 (to J.B.), AHA 0640100N (to D.U.).

\section{References}

1. Frank DN, St Amand AL, Feldman RA, et al. Molecular-phylogenetic characterization of microbial community imbalances in human inflammatory bowel diseases. Proc Natl Acad Sci USA. 2007; 104:13780-13785. [PubMed: 17699621]

2. Sartor RB. Probiotic therapy of intestinal inflammation and infections. Curr Opin Gastroenterol. 2005; 21:44-50. [PubMed: 15687884]

3. Landers CJ, Cohavy O, Misra R, et al. Selected loss of tolerance evidenced by Crohn's diseaseassociated immune responses to auto-and microbial antigens. Gastroenterology. 2002; 123:689-699. [PubMed: 12198693]

4. Barnich N, Carvalho FA, Glasser AL, et al. CEACAM6 acts as a receptor for adherent-invasive E. coli, supporting ileal mucosa colonization in Crohn disease. J Clin Invest. 2007; 117:1566-1574. [PubMed: 17525800]

5. Mei L, Targan SR, Landers CJ, et al. Familial expression of anti-Escherichia coli outer membrane porin $\mathrm{C}$ in relatives of patients with Crohn's disease. Gastroenterology. 2006; 130:1078-1085. [PubMed: 16618402]

6. Cohavy O, Bruckner D, Eggena ME, et al. Colonic bacteria express an ulcerative colitis pANCArelated protein epitope. Infect Immun. 2000; 68:1542-1548. [PubMed: 10678972]

7. Targan SR, Landers CJ, Yang H, et al. Antibodies to CBir1 flagellin define a unique response that is associated independently with complicated Crohn's disease. Gastroenterology. 2005; 128:2020 2028. [PubMed: 15940634]

8. Vannuffel P, Dieterich C, Naerhuyzen B, et al. Occurrence, in Crohn's disease, of antibodies directed against a species-specific recombinant polypeptide of Mycobacterium paratuberculosis. Clin Diagn Lab Immunol. 1994; 1:241-243. [PubMed: 7496954] 
9. El-Zaatari FA, Naser SA, Hulten K, et al. Characterization of Mycobacterium paratuberculosis p36 antigen and its seroreactivities in Crohn's disease. Curr Microbiol. 1999; 39:115-119. [PubMed: 10398839]

10. Naser SA, Hulten K, Shafran I, et al. Specific seroreactivity of Crohn's disease patients against p35 and p36 antigens of M. avium subsp. paratuberculosis. Vet Microbiol. 2000; 77:497-504. [PubMed: 11118734]

11. Naser SA, Schwartz D, Shafran I. Isolation of Mycobacterium avium subsp paratuberculosis from breast milk of Crohn's disease patients. Am J Gastroenterol. 2000; 95:1094-1095. [PubMed: 10763975]

12. Elsaghier A, Prantera C, Moreno C, et al. Antibodies to Mycobacterium paratuberculosis-specific protein antigens in Crohn's disease. Clin Exp Immunol. 1992; 90:503-508. [PubMed: 1281056]

13. Greenstein RJ. Is Crohn's disease caused by a mycobacterium? Comparisons with leprosy, tuberculosis, and Johne's disease. Lancet Infect Dis. 2003; 3:507-514. [PubMed: 12901893]

14. Scupham AJ, Presley LL, Wei B, et al. Abundant and diverse fungal microbiota in the murine intestine. Appl Environ Microbiol. 2006; 72:793-801. [PubMed: 16391120]

15. Kuhbacher T, Ott SJ, Helwig U, et al. Bacterial and fungal microbiota in relation to probiotic therapy (VSL\#3) in pouchitis. Gut. 2006; 55:833-841. [PubMed: 16401690]

16. Heelan BT, Allan S, Barnes RMR. Identification of a $200 \mathrm{kDa}$ glycoprotein antigen of Saccharomyces cerevisiae. Immunol Lett. 1991; 28:181-186. [PubMed: 1885214]

17. Barnes RMR, Allan S, Taylor-Robinson $\mathrm{CH}$, et al. Serum antibodies reactive with Saccharomyces cerevisiae in inflammatory bowel disease: is IgA antibody a marker for Crohn's disease? Int Arch Allergy Appl Immunol. 1990; 92:9-15. [PubMed: 2246081]

18. McKenzie H, Main J, Pennington CR, et al. Antibody to selected strains of Saccharomyces cerevisiae (baker's and brewer's yeast) and Candida albicans in Crohn's disease. Gut. 1990; 31:536-538. [PubMed: 2190866]

19. Quinton JF, Sendid B, Reumaux D, et al. Anti-Saccharomyces cerevisiae mannan antibodies combined with antineutrophil cytoplasmic autoantibodies in inflammatory bowel disease: prevalence and diagnostic role. Gut. 1998; 42:788-791. [PubMed: 9691915]

20. Giaffer MH, Clark A, Holdsworth CD. Antibodies to Saccharomyces cerevisiae in patients with Crohn's disease and their possible pathogenic importance. Gut. 1992; 33:1071-1075. [PubMed: 1398231]

21. Dotan I, Fishman S, Dgani Y, et al. Antibodies against laminaribioside and chitobioside are novel serologic markers in Crohn's disease. Gastroenterology. 2006; 131:366-378. [PubMed: 16890590]

22. Sendid B, Colombel JF, Jacquinot PM, et al. Specific antibody response to oligomannosidic epitopes in Crohn's disease. Clin Diag Lab Immunol. 1996; 3:219-226.

23. McKenzie H, Parratt D, Main J, et al. Antigenic heterogeneity of strains of Saccharomyces cerevisiae and Candida albicans recognised by serumantibodies from patients with Crohn's disease. FEMS Microbiol Immunol. 1992; 89:219-224. [PubMed: 1599707]

24. Schaffer T, Muller S, Flogerzi B, et al. Anti-Saccharomyces cerevisiae mannan antibodies (ASCA) of Crohn's patients crossreact with mannan from other yeast strains, and murine ASCA IgM can be experimentally induced with Candida albicans. Inflamm Bowel Dis. 2007; 13:1339-1346. [PubMed: 17636567]

25. Standaert-Vitse A, Jouault T, Vandewalle P, et al. Candida albicans is an immunogen for antiSaccharomyces cerevisiae antibody markers of Crohn's disease. Gastroenterology. 2006; 130:1764-1775. [PubMed: 16697740]

26. Davidson IW, Lloyd RS, Whorwell PJ, et al. Antibodies to maize in patients with Crohn's disease, ulcerative colitis and coeliac disease. Clin Exp Immunol. 1979; 35:147-148. [PubMed: 371884]

27. Sonnenberg A. Occupational distribution of inflammatory bowel disease among German employees. Gut. 1990; 31:1037-1040. [PubMed: 2210450]

28. Young CA, Sonnenberg A, Burns EA. Lymphocyte proliferation response to Baker's yeast in Crohn's disease. Digestion. 1994; 55:40-43. [PubMed: 8112496]

29. Konrad A, Rutten C, Flogerzi B, et al. Immune sensitization to yeast antigens in ASCA-positive patients with Crohn's disease. Inflamm Bowel Dis. 2004; 10:97-105. [PubMed: 15168808] 
30. Vermeire S, Peeters M, Vlietinck R, et al. Anti-Saccharomyces cerevisiae antibodies (ASCA), phenotypes of IBD, and intestinal permeability: a study in IBD families. Inflamm Bowel Dis. 2001; 7:8-15. [PubMed: 11233666]

31. Seibold F, Stich O, Hufnagl R, et al. Anti-Saccharomyces cerevisiae antibodies in inflammatory bowel disease: a family study. Scand J Gastroenterol. 2001; 36:196-201. [PubMed: 11252413]

32. Sendid B, Quinton JF, Charrier G, et al. Anti-Saccharomyces cerevisiae mannan antibodies in familial Crohn's disease. Am J Gastroenterol. 1998; 93:1306-1310. [PubMed: 9707056]

33. Sutton C, Yang HY, Rotter JI, et al. Familial expression of anti-Saccharomyces cerevisiae mannan antibodies (ASCA) in affected and unaffected relatives of Crohn's disease patients. Gut. 2000; 46:58-63. [PubMed: 10601056]

34. Israeli E, Grotto I, Gilburd B, et al. Anti-Saccharomyces cerevisiae and antineutrophil cytoplasmic antibodies as predictors of inflammatory bowel disease. Gut. 2005; 54:1232-1236. [PubMed: 16099791]

35. Walker LJ, Aldhous MC, Drummond HE, et al. Anti-Saccharomyces cerevisiae antibodies (ASCA) in Crohn's disease are associated with disease severity but not NOD2/CARD15 mutations. Clin Exp Immunol. 2004; 135:490-496. [PubMed: 15008984]

36. Gupta N, Cohen SA, Bostrom AG, et al. Risk factors for initial surgery in pediatric patients with Crohn's disease. Gastroenterology. 2006; 130:1069-1077. [PubMed: 16618401]

37. Mow WS, Vasiliauskas EA, Lin YC, et al. Association of antibody responses to microbial antigens and complications of small bowel Crohn's disease. Gastroenterology. 2004; 126:414-424. [PubMed: 14762777]

38. Ferrante M, Henckaerts L, Joossens M, et al. New serological markers in inflammatory bowel disease are associated with complicated disease behaviour. Gut. 2007; 56:1394-1403. [PubMed: 17456509]

39. Lawrance IC, Fiocchi C, Chakravarti S. Ulcerative colitis and Crohn's disease: distinctive gene expression profiles and novel susceptibility candidate genes. Hum Mol Genet. 2001; 10:445-456. [PubMed: 11181568]

40. Costello CM, Mah N, Hasler R, et al. Dissection of the inflammatory bowel disease transcriptome using genome-wide cDNA microarrays. PLoS Med. 2005; 2:e199. [PubMed: 16107186]

41. Hugot JP, Laurent-Puig P, Gower-Rousseau C, et al. Mapping of a susceptibility locus for Crohn's disease on chromosome 16. Nature. 1996; 379:821-823. [PubMed: 8587604]

42. Annese V, Latiano A, Bovio P, et al. Genetic analysis in Italian families with inflammatory bowel disease supports linkage to the IBD1 locus—a GISC study. Eur J Hum Genet. 1999; 7:567-573. [PubMed: 10439963]

43. Cho JH, Nicolae DL, Gold LH, et al. Identification of novel susceptibility loci for inflammatory bowel disease on chromosomes 1p, 3q, and 4q: evidence for epistasis between 1p and IBD1. Proc Natl Acad Sci USA. 1998; 95:7502-7507. [PubMed: 9636179]

44. Libioulle C, Louis E, Hansoul S, et al. Novel Crohn disease locus identified by genome-wide association maps to a gene desert on 5p13.1 and modulates expression of PTGER4. PLoS Genet. 2007; 3:e58. [PubMed: 17447842]

45. Duerr RH, Barmada MM, Zhang L, et al. Linkage and association between inflammatory bowel disease and a locus on chromosome 12. Am J Hum Genet. 1998; 63:95-100. [PubMed: 9634527]

46. Duerr RH, Taylor KD, Brant SR, et al. A genome-wide association study identifies IL23R as an inflammatory bowel disease gene. Science. 2006; 314:1461-1463. [PubMed: 17068223]

47. Simmons JD, Mullighan C, Welsh KI, et al. Vitamin D receptor gene polymorphism: association with Crohn's disease susceptibility. Gut. 2000; 47:211-214. [PubMed: 10896912]

48. Kozaiwa K, Sugawara K, Smith MF Jr, et al. Identification of a quantitative trait locus for ileitis in a spontaneous mouse model of Crohn's disease: SAMP1/YitFc. Gastroenterology. 2003; 125:477490. [PubMed: 12891551]

49. Sugawara K, Olson TS, Moskaluk CA, et al. Linkage to peroxisome proliferator-activated receptor-gamma in SAMP1/YitFc mice and in human Crohn's disease. Gastroenterology. 2005; 128:351-360. [PubMed: 15685547] 
50. Stokkers PC, Huibregtse K Jr, Leegwater AC, et al. Analysis of a positional candidate gene for inflammatory bowel disease: NRAMP2. Inflamm Bowel Dis. 2000; 6:92-98. [PubMed: 10833067]

51. Rioux JD, Xavier RJ, Taylor KD, et al. Genome-wide association study identifies new susceptibility loci for Crohn disease and implicates autophagy in disease pathogenesis. Nat Genet. 2007; 39:596-604. [PubMed: 17435756]

52. Hampe J, Cuthbert A, Croucher PJ, et al. Association between insertion mutation in NOD2 gene and Crohn's disease in German and British populations. Lancet. 2001; 357:1925-1928. [PubMed: 11425413]

53. Watanabe T, Kitani A, Murray PJ, et al. Nucleotide binding oligomerization domain 2 deficiency leads to dysregulated TLR2 signaling and induction of antigen-specific colitis. Immunity. 2006; 25:473-485. [PubMed: 16949315]

54. Smith BR, Arnott ID, Drummond HE, et al. Disease location, anti-Saccharomyces cerevisiae antibody, and NOD2/CARD15 genotype influence the progression of disease behavior in Crohn's disease. Inflamm Bowel Dis. 2004; 10:521-528. [PubMed: 15472511]

55. Annese V, Lombardi G, Perri F, et al. Variants of CARD15 are associated with an aggressive clinical course of Crohn's disease—an IG-IBD study. Am J Gastroenterol. 2005; 100:84-92. [PubMed: 15654786]

56. Castro-Santos P, Mozo L, Gutierrez C, et al. TNFalpha genotype influences development of IgAASCA antibodies in Crohn's disease patients with CARD15 wild type. Clin Immunol. 2006; 121:305-313. [PubMed: 16952484]

57. Dassopoulos T, Frangakis C, Cruz-Correa M, et al. Antibodies to Saccharomyces cerevisiae in Crohn's disease: higher titers are associated with a greater frequency of mutant NOD2/CARD15 alleles and with a higher probability of complicated disease. Inflamm Bowel Dis. 2007; 13:143151. [PubMed: 17206688]

58. Lemaitre B, Nicolas E, Michaut L, et al. The dorsoventral regulatory gene cassette spatzle/Toll/ cactus controls the potent antifungal response in Drosophila adults. Cell. 1996; 86:973-983. [PubMed: 8808632]

59. Underhill DM, Ozinsky A, Smith KD, et al. Toll-like receptor-2 mediates mycobacteria-induced proinflammatory signaling in macrophages. Proc Natl Acad Sci USA. 1999; 96:14459-14463. [PubMed: 10588727]

60. Ozinsky A, Underhill DM, Fontenot JD, et al. The repertoire for pattern recognition of pathogens by the innate immune system is defined by cooperation between toll-like receptors. Proc Natl Acad Sci USA. 2000; 97:13766-13771. [PubMed: 11095740]

61. Netea MG, Van Der Graaf CA, Vonk AG, et al. The role of toll-like receptor (TLR) 2 and TLR4 in the host defense against disseminated candidiasis. J Infect Dis. 2002; 185:1483-1489. [PubMed: 11992285]

62. Van der Graaf CA, Netea MG, Morre SA, et al. Toll-like receptor 4 Asp299Gly/Thr399Ile polymorphisms are a risk factor for Candida bloodstream infection. Eur Cytokine Netw. 2006; 17:29-34. [PubMed: 16613760]

63. Meier A, Kirschning CJ, Nikolaus T, et al. Toll-like receptor (TLR) 2 and TLR4 are essential for Aspergillus-induced activation of murine macrophages. Cell Microbiol. 2003; 5:561-570. [PubMed: 12864815]

64. Netea MG, Warris A, Van der Meer JW, et al. Aspergillus fumigatus evades immune recognition during germination through loss of toll-like receptor-4-mediated signal transduction. J Infect Dis. 2003; 188:320-326. [PubMed: 12854089]

65. Gersuk GM, Underhill DM, Zhu L, et al. Dectin-1 and TLRs permit macrophages to distinguish between different Aspergillus fumigatus cellular states. J Immunol. 2006; 176:3717-3724. [PubMed: 16517740]

66. De Jager PL, Franchimont D, Waliszewska A, et al. The role of the Toll receptor pathway in susceptibility to inflammatory bowel diseases. Genes Immun. 2007; 8:387-397. [PubMed: 17538633]

67. Franchimont D, Vermeire S, El Housni H, et al. Deficient host-bacteria interactions in inflammatory bowel disease? The toll-like receptor (TLR)-4 Asp299gly polymorphism is 
associated with Crohn's disease and ulcerative colitis. Gut. 2004; 53:987-992. [PubMed: 15194649]

68. Fukata M, Michelsen KS, Eri R, et al. Toll-like receptor-4 is required for intestinal response to epithelial injury and limiting bacterial translocation in a murine model of acute colitis. Am J Physiol Gastrointest Liver Physiol. 2005; 288:G1055-1065. [PubMed: 15826931]

69. Rakoff-Nahoum S, Paglino J, Eslami-Varzaneh F, et al. Recognition of commensal microflora by toll-like receptors is required for intestinal homeostasis. Cell. 2004; 118:229-241. [PubMed: 15260992]

70. Heimesaat MM, Fischer A, Siegmund B, et al. Shift towards proinflammatory intestinal bacteria aggravates acute murine colitis via Toll-like receptors 2 and 4. PLoS ONE. 2007; 2:e662. [PubMed: 17653282]

71. Rakoff-Nahoum S, Hao L, Medzhitov R. Role of toll-like receptors in spontaneous commensaldependent colitis. Immunity. 2006; 25:319-329. [PubMed: 16879997]

72. Klis FM, de Groot P, Hellingwerf K. Molecular organization of the cell wall of Candida albicans. Med Mycol. 2001; 39(Suppl 1):1-8. [PubMed: 11800263]

73. Ariizumi K, Shen GL, Shikano S, et al. Identification of a novel, dendritic cell-associated molecule, dectin-1, by subtractive cDNA cloning. J Biol Chem. 2000; 275:20157-20167. [PubMed: 10779524]

74. Taylor PR, Brown GD, Reid DM, et al. The beta-glucan receptor, dectin-1, is predominantly expressed on the surface of cells of the monocyte/macrophage and neutrophil lineages. J Immunol. 2002; 169:3876-3882. [PubMed: 12244185]

75. Barrow AD, Trowsdale J. You say ITAM and I say ITIM, let's call the whole thing off: the ambiguity of immunoreceptor signalling. Eur J Immunol. 2006; 36:1646-1653. [PubMed: 16783855]

76. Gantner BN, Simmons RM, Canavera SJ, et al. Collaborative induction of inflammatory responses by dectin-1 and Toll-like receptor 2. J Exp Med. 2003; 197:1107-1117. [PubMed: 12719479]

77. Herre J, Marshall AS, Caron E, et al. Dectin-1 uses novel mechanisms for yeast phagocytosis in macrophages. Blood. 2004; 104:4038-4045. [PubMed: 15304394]

78. Rogers NC, Slack EC, Edwards AD, et al. Syk-dependent cytokine induction by Dectin-1 reveals a novel pattern recognition pathway for $C$ type lectins. Immunity. 2005; 22:507-517. [PubMed: 15845454]

79. Underhill DM, Rossnagle E, Lowell CA, et al. Dectin-1 activates Syk tyrosine kinase in a dynamic subset of macrophages for reactive oxygen production. Blood. 2005; 106:2543-2550. [PubMed: 15956283]

80. Gross O, Gewies A, Finger K, et al. Card9 controls a non-TLR signalling pathway for innate antifungal immunity. Nature. 2006; 442:651-656. [PubMed: 16862125]

81. Hara H, Ishihara C, Takeuchi A, et al. The adaptor protein CARD9 is essential for the activation of myeloid cells through ITAM-associated and Toll-like receptors. Nat Immunol. 2007; 8:619-629. [PubMed: 17486093]

82. Hsu YM, Zhang Y, You Y, et al. The adaptor protein CARD9 is required for innate immune responses to intracellular pathogens. Nat Immunol. 2007; 8:198-205. [PubMed: 17187069]

83. Ross GD. Regulation of the adhesion versus cytotoxic functions of the Mac-1/CR3/alphaMbeta2integrin glycoprotein. Crit Rev Immunol. 2000; 20:197-222. [PubMed: 10968371]

84. Ross GD, Cain JA, Lachmann PJ. Membrane complement receptor type three (CR3) has lectin-like properties analogous to bovine conglutinin as functions as a receptor for zymosan and rabbit erythrocytes as well as a receptor for iC3b. J Immunol. 1985; 134:3307-3315. [PubMed: 2984286]

85. Li B, Allendorf DJ, Hansen R, et al. Yeast beta-glucan amplifies phagocyte killing of iC3bopsonized tumor cells via complement receptor 3-Syk-phosphatidylinositol 3-kinase pathway. J Immunol. 2006; 177:1661-1669. [PubMed: 16849475]

86. Abram CL, Lowell CA. Convergence of immunoreceptor and integrin signaling. Immunol Rev. 2007; 218:29-44. [PubMed: 17624942]

87. Mocsai A, Zhou M, Meng F, et al. Syk is required for integrin signaling in neutrophils. Immunity. 2002; 16:547-558. [PubMed: 11970878] 
88. Linehan SA, Martinez-Pomares L, Gordon S. Macrophage lectins in host defence. Microbes Infect. 2000; 2:279-288. [PubMed: 10758404]

89. McGreal EP, Rosas M, Brown GD, et al. The carbohydrate-recognition domain of Dectin-2 is a Ctype lectin with specificity for high mannose. Glycobiology. 2006; 16:422-430. [PubMed: 16423983]

90. Sato K, Yang XL, Yudate T, et al. Dectin-2 is a pattern recognition receptor for fungi that couples with the Fc receptor gamma chain to induce innate immune responses. J Biol Chem. 2006; 281:38854-38866. [PubMed: 17050534]

91. Cambi A, Gijzen K, de Vries JM, et al. The C-type lectin DC-SIGN (CD209) is an antigen-uptake receptor for Candida albicans on dendritic cells. Eur J Immunol. 2003; 33:532-538. [PubMed: 12645952]

92. Serrano-Gomez D, Leal JA, Corbi AL. DC-SIGN mediates the binding of Aspergillus fumigatus and keratinophylic fungi by human dendritic cells. Immunobiology. 2005; 210:175-183. [PubMed: 16164024]

93. Takahara K, Yashima Y, Omatsu Y, et al. Functional comparison of the mouse DC-SIGN, SIGNR1, SIGNR3 and Langerin, C-type lectins. Int Immunol. 2004; 16:819-829. [PubMed: 15096474]

94. Taylor PR, Brown GD, Herre J, et al. The role of SIGNR1 and the beta-glucan receptor (dectin-1) in the nonopsonic recognition of yeast by specific macrophages. J Immunol. 2004; 172:11571162. [PubMed: 14707091]

95. Wieland CW, Koppel EA, den Dunnen J, et al. Mice lacking SIGNR1 have stronger T helper 1 responses to Mycobacterium tuberculosis. Microbes Infect. 2007; 9:134-141. [PubMed: 17224292]

96. Gringhuis SI, den Dunnen J, Litjens M, et al. C-type lectin DC-SIGN modulates Toll-like receptor signaling via Raf-1 kinase-dependent acetylation of transcription factor NF-kappaB. Immunity. 2007; 26:605-616. [PubMed: 17462920]

97. Dennehy KM, Brown GD. The role of the beta-glucan receptor Dectin-1 in control of fungal infection. J Leukocyte Biol. 2007; 82:253-258. [PubMed: 17475782]

98. Stahl PD, Ezekowitz RA. The mannose receptor is a pattern recognition receptor involved in host defense. Curr Opin Immunol. 1998; 10:50-55. [PubMed: 9523111]

99. Lillegard JB, Sim RB, Thorkildson P, et al. Recognition of Candida albicans by mannan-binding lectin in vitro and in vivo. J Infect Dis. 2006; 193:1589-1597. [PubMed: 16652289]

100. Garlanda C, Hirsch E, Bozza S, et al. Non-redundant role of the long PTX3 in anti-fungal innate immune response. Nature. 2002; 420:182-186. [PubMed: 12432394] 
TABLE 1

Innate Receptors Involved in Fungal Recognition

\begin{tabular}{llll}
\hline Receptor & Family & Ligand(s) & Reference(s) \\
\hline Membrane: & & & \\
Toll-like receptors & Leucine-rich repeat & Various & $(58,59,61)$ \\
Dectin-1 & C-type Lectin & $\beta$-Glucan & $(97)$ \\
Dectin-2 & C-type Lectin & Mannan & $(89,90)$ \\
Mannose receptor & C-type Lectin & Mannan & $(98)$ \\
DC-SIGN & C-type Lectin & Mannan & $(92,93)$ \\
DC-SIGNR/SIGNR1 & C-type Lectin & Mannan & $(93,94)$ \\
Complement receptor 3 & Integrin & Complement, $\beta$-glucan & $(85)$ \\
Soluble: & & & \\
Mannose-binding protein & C-type Lectin & Mannan & $(99)$ \\
Pentraxin 3 & Pentraxin & Various & $(100)$ \\
\hline
\end{tabular}

